\title{
PROFIL KOMPETENSI PRODUKTIF SISWA SMK TKR DALAM RANGKA SERTIFIKASI KEAHLIAN UNTUK PERSAINGAN GLOBAL
}

\section{PRODUCTIVE COMPETENCE PROFILE OF SMK TKR STUDENTS IN THE FRAMEWORK OF EXPERTISE CERTIFICATION FOR GLOBAL COMPETITION}

\author{
Muhkamad Wakid ${ }^{1}$, Tafakur ${ }^{2}$ \\ Jurusan Pendidikan Teknik Otomotif FT UNY \\ E-mail: wakid_m@uny.ac.id
}

\begin{abstract}
ABSTRAK
Diberlakukannya Masyarakat Ekonomi ASEAN menuntut kesiapan dan pengakuan kompetensi tenaga kerja untuk menghadapi persaingan bebas. Di Indonesia, pemerintah menargetkan peningkatan jumlah penyelenggaraan SMK untuk menyiapkan lulusan yang siap kerja. Namun faktanya pengangguran lulusan SMK masih tinggi, meskipun banyak sekolah telah melakukan uji kompetensi serta program sertifikasi bagi lulusannya. Untuk melihat uji kompetensi di SMK, perlu diketahui materi uji, asesor, hasil uji, serta sertifikasinya. Penelitian survei dilakukan pada SMK Negeri Paket Keahlian Teknik Kendaraan Ringan (TKR) di DIY. Hasil penelitian menunjukkan: (1) Materi uji kompetensi TKR memiliki 2 model. Model 1 menggunakan 4 soal uji, sedangkan model 2 menggunakan 8 soal, (2) Asesor terdiri dari pihak internal guru produktif dan penguji eksternal dari industri jasa servis kendaraan dan balai latihan kerja. Hasil Uji dilihat dari nilainya sangat baik, namun belum mencerminkan kompetensi sebenarnya. Siswa yang lulus uji mendapatkan sertifikat dari SMK bekerjasama dengan mitranya, yaitu bengkel servis kendaraan, MPKD, dan BLK.
\end{abstract}

Kata kunci: Uji kompetensi, Sertifikasi

\section{ABSTRACT}

The implementation of ASEAN Economic Community requires the readiness and competency of employees to face the free trade. The Indonesian government aims at the increasing number of VHS to prepare students ready to work. However, the unemployment of VHS students is still high, even many schools have conducted the competency assessment and certification program. Assessment materials, assessors, results and validation are needed to know the competency test at VHS. The survey was conducted at Automotive Engineering department at VHS in DIY. The survey results showed: (1) the assessment materials had 2 models. Model 1 employed 4 questions and Model 2 used 8 questions, (2) the assessors consisted of productive teachers, the auto service and labour training centers. The test results were very good, yet they had not showed the real competency. The students who passed the test were given a certificate from VHS and the partnership: auto service centers, MPKD, and labour training centers.

Keywords: Competence assessment, Certification

\section{PENDAHULUAN}

Globalisasi dengan segala keterbukaannya mengikat hampir semua negara di dunia, sehingga memaksa terjadinya saling kerjasama antar bangsa dan antar negara yang mengakibatkan adanya saling ketergantungan. Globalisasi juga menimbulkan persaingan antar negara di dunia sehingga beberapa negara membentuk kelompok sendiri pada kawasan, alasan dan agenda tertentu, misalnya alasan ekonomi, alasan pertahanan, dan alasan ideologi.

Globalisasi juga berdampak pada berbagai aspek kehidupan di setiap negara. Salah satu dampak globalisasi yang melanda Indonesia adalah dengan diterapkannya Masyarakat Ekonomi ASEAN (MEA) atau ASEAN Economic Community (AEC) di akhir tahun 2015. Dalam hal ini globalisasi di bidang ekonomi digencarkan meskipun akan berdampak pada aspek kehidupan lainnya. 
Masyarakat Ekonomi ASEAN (MEA) adalah bentuk integrasi ekonomi negara-negara ASEAN yaitu adanya sistem perdagangan bebas di antara negara-negara ASEAN. Indonesia dan sembilan negara anggota ASEAN lainnya telah menyepakati adanya perjanjian Masyarakat Ekonomi ASEAN (MEA) tersebut. (http://seputarpengertian. blogspot.com/2014/08/Pengertian-karakteristikmasyarakat-ekonomi-asean.html, diunduh 18 Desember 2014 jam 22.00 WIB).

Dengan diterapkannya MEA, seluruh negara ASEAN diharuskan melakukan liberalisasi (kebebasan), yaitu: (1) arus bebas barang, (2) arus bebas jasa, (3) arus bebas investasi, (4) arus modal yang lebih bebas, dan (5) arus bebas tenaga kerja terampil (Anonim, t.th.: 18 - 41). Meskipun MEA merupakan globalisasi di bidang ekonomi, namun dengan adanya arus keluar-masuk tenaga kerja secara bebas akan berimplikasi luas dalam bidang pendidikan, terutama pendidikan vokasional.

Agar tidak sekedar menjadi tempat tujuan arus masuk ke lima hal di atas, maka bangsa Indonesia harus pandai dalam memanfaatkan peluang secara proaktif. Peluang tersebut meliputi: (1) adanya integrasi ekonomi, (2) adanya pasar potensial dunia, (3) menjadi negara pengekspor (10 komoditi ekspor), (4) ada negara tujuan investor, (5) ada daya saing, (6) ada sektor jasa yang terbuka, dan (7) ada aliran modal. Tantangan yang muncul adalah: (1) Laju peningkatan ekspor dan impor, (2) Laju inflasi, (3) dampak negatif arus modal yang lebih bebas, (4) kesamaan produk, (5) daya saing sektor prioritas tinggi, (6) daya saing SDM, (7) tingkat perkembangan ekonomi, (8) kepentingan nasional, (9) kedaulatan negara. (Anonim, t.th.: 74-82). Untuk menghadapi peluang dan tantangan tersebut, Departemen Perdagangan RI telah menyusun 10 langkah strategis. Salah satu di antaranya adalah peningkatan kualitas sumber daya manusia (SDM) baik dalam birokrasi, dunia usaha maupun profesional. Dengan kuatnya SDM, maka tenaga kerja dari dalam negeri akan mampu bersaing secara terbuka dengan tenaga kerja dari luar. Daya saing tenaga kerja harus ditingkatkan baik secara formal maupun informal. Sebagai bentuk nyatanya, diperlukan sebuah sistem pendidikan yang menyeluruh dan pengakuan kompetensi lulusan melalui sertifikasi berbagai profesi.

Kondisi ketenagakerjaan di Indonesia bila dilihat dari pendidikan yang ditamatkan secara lengkap dapat dilihat pada Tabel 1 (Badan Pusat Statistik, 2014: 1-5) di bawah ini.

Tabel 1. Penduduk Usia 15 Tahun Ke Atas yang Bekerja Menurut Pendidikan Tertinggi yang Ditamatkan, 2012-2014 (juta orang)

\begin{tabular}{|c|c|c|c|c|c|}
\hline \multirow{2}{*}{ Pendidikan tertinggi yang ditamatkan } & \multicolumn{2}{|c|}{2012} & \multicolumn{2}{|l|}{2013} & \multirow{2}{*}{$\begin{array}{c}2014 \\
\text { Februari }\end{array}$} \\
\hline & Februari & Agustus & Februari & Agustus & \\
\hline (1) & (2) & (3) & (4) & $(5)$ & $(6)$ \\
\hline SD ke bawah & 57,33 & 55,62 & 56,49 & 53,81 & 55,31 \\
\hline Sekolah Menengah Pertama & 20,34 & 20,27 & 20,36 & 20,56 & 21,06 \\
\hline Sekolah Menengah Atas & 17,34 & 17,40 & 17,95 & 17,88 & 18,91 \\
\hline Sekolah Menengah Kejuruan & 9,55 & 9,61 & 10,32 & 9,97 & 10,91 \\
\hline Diploma I/II/III & 3,15 & 3,01 & 3,25 & 2,93 & 3,13 \\
\hline Universitas & 7,37 & 7,10 & 8,07 & 7,61 & 8,85 \\
\hline Jumlah & 115,08 & 113,01 & 116,44 & 112,76 & 118,17 \\
\hline
\end{tabular}

Berdasarka data pada tabel 1 di atas, ditunjukkan bahwa pada Februari 2014 sebagian besar tenaga kerja adalah berpendidikan SD ke bawah 45,1 persen, berpendidikan SMP sebesar 17,82 persen, berpendidikan SMA sebesar 16 persen, berpendidikan SMK sebesar 9,31 persen, dan sisanya 10,13 persen berpendidikan vokasi dan 
universitas. Berdasarkan data tersebut maka tenaga kerja yang potensial dikembangkan adalah sekitar 35,44 persen yaitu bependidikan SMA, SMK, vokasi dan universitas. Jumlah tersebut masih kecil, dan belum jelas untuk kualitasnya, karena 64, 56 persen masih rendah pendidikannya. Kaitannya dengan pendidikan vokasi, Evan (1971: 1) menyatakan bahwa:" ..vocational education is that part of education which makes an individual more employable in one group of occupations than in another". Thompson (1973: 216) menambahkan bahwa: "Vocational education is any education that provides experiences, visual stimuli, affective awareness, cognitive information, or psychomotor skills; and that enhances the vocational development process of exploring, establishing, and maintaining oneself in the world of work. Clarke dan Winch (2007: 9) juga menyatakan bahwa:" ..vocational education is confined to preparing young people and adults for working life, a process often regarded as of a rather technical and practical nature." Billet (2011: 61) juga merumuskan bahwa: "vocational education is seen as being primarily about providing an effective preparation and smooth transition for students into the occupational practices of the kinds needed in the community".

Empat pengertian pendidikan kejuruan/vokasi di atas menunjukkan bahwa pendidikan kejuruan mempunyai tugas memberikan pengalaman belajar kepada peserta didik agar setelah lulus dapat memasuki dunia kerja sesuai bidangnya. Dengan demikian, pendidikan kejuruan mestinya dapat menjadi solusi untuk menciptakan tenaga kerja handal dan terhindar dari pengangguran.

Dilihat dari keadaan Tingkat Pengangguran Terbuka (TPT) ditinjau dari tingkat pendidikan dapat dilihat pada Tabel 2 (Badan Pusat Statistik, 2014: 1-5).

Tabel 2. Tingkat Pengangguran Terbuka (TPT) Penduduk Usia 15 Tahun Ke Atas Menurut Pendidikan Tertinggi yang Ditamatkan, 2012-2014 (persen)

\begin{tabular}{|c|c|c|c|c|c|}
\hline \multirow{2}{*}{ Pendidikan tertinggi yang ditamatkan } & \multicolumn{2}{|c|}{2012} & \multicolumn{2}{|l|}{2013} & \multirow{2}{*}{ Februari } \\
\hline & Februari & Agustus & Februari & Agustus & \\
\hline (1) & (2) & (3) & (4) & (5) & $(6)$ \\
\hline SD ke bawah & 3,59 & 3,55 & 3,51 & 3,44 & 3,69 \\
\hline Sekolah Menengah Pertama & 7,76 & 7,75 & 8,17 & 7,59 & 7,44 \\
\hline Sekolah Menengah Atas & 10,41 & 9,63 & 9,39 & 9,72 & 9,10 \\
\hline Sekolah Menengah Kejuruan & 9,50 & 9,92 & 7,67 & 11,21 & 7,21 \\
\hline Diploma I/II/III & 7,45 & 6,19 & 5,67 & 5,95 & 5,87 \\
\hline Universitas & 6,90 & 5,88 & 4,96 & 5,39 & 4,31 \\
\hline
\end{tabular}

Berdasarkan data TPT di atas, dari Februari 2012 sampai Februari 2014 telah terjadi penurunan persentase TPT. Namun, penurunan tersebut masih lambat, sehingga perlu ditingkatkan.

Dilihat dari jumlah pengangguran, laporan Badan Pusat Statistik (BPS) menyatakan bahwa jumlah pengangguran terbanyak adalah lulusan SMK mencapai 813 776 orang atau 11.24 persen dari total tingkat pengangguran terbuka. Suryamin mengatakan fakta ini harus menjadi perhatian pemerintah, sebab lulusan SMK yang sejatinya dibekali ilmu kerja, justru menjadi yang paling banyak tidak terserap tenaga kerjanya. (http://www.republika.co.id/berita/ ekonomi/ makro/14/11/05/ nekbam-bps- lulusan-smkpaling- banyak- menganggur, diunduh 3 Januari 2015 jam 11.44 WIB).

Salah satu bidang kerja yang berkembang untuk menyerap tenaga kerja adalah bidang Teknik Kendaraan Ringan. Untuk menyiapkan tenaga kerjanya diselenggarakan program pendidikan SMK. Keadaan SMK pada tahun 2009-2014 dapat dilihat pada Roadmap Pengembangan 
Pendidikan Kejuruan yang dipaparkan oleh Direktur Pembinaan SMK Direktorat Jenderal Pendidikan Menengah Kementerian Pendidikan dan Kebudayaan di dalam Seminar Nasional Jurusan Pendidikan Teknik Elektro FT UNY di Yogyakarta pada tanggal 6
November 2014. Dalam Roadmap tersebut dinyatakan bahwa terjadi perkembangan jumlah SMK, jumlah siswa SMK, dan jumlah guru SMK di setiap tahunnya yang dapat dilihat pada tabel 3 .

Tabel 3. Roadmap Perkembangan Pendidikan Kejuruan Tahun 2009 - 2014

\begin{tabular}{lcccccc}
\hline \multicolumn{1}{c}{ Kondisi } & 2009 & 2010 & 2011 & 2012 & 2013 & 2014 \\
\hline Jumlah SMK & 8593 & 9164 & 9918 & 10685 & 11708 & 11748 \\
Jumlah Siswa SMK & 3276921 & 3737158 & 4019157 & 4189519 & 4372406 & 4512063 \\
Jumlah Guru SMK & 122622 & 135930 & 156268 & 179000 & 197000 & 219000 \\
\hline
\end{tabular}

Dari Tabel 3 di atas dapat dilihat bahwa terjadi kenaikan jumlah SMK setiap tahunnya sebesar 571, 754, 767, 1023. Jumlah siswa SMK meningkat secara bervariasi sekitar 200 ribu per tahun. Animo lulusan SMP yang akan masuk SMK setiap tahun meningkat 11\% dengan total pendaftar 1921919 orang calon siswa pada tahun 2013. Namun demikian ratarata kenaikan daya tampung SMK hanya 5\% dan di tahun 2013 hanya menerima 1527778 siswa. Dengan demikian di tahun 2013 masih ada sekitar 400 ribu calon yang tidak tertampung di SMK.

Dilihat dari tingkat kebekerjaannya, (employability) lulusan SMK pada tahun 2013/2014 dari jumlah lulusan SMK sebesar 1 241398 orang yang bekerja 804674 orang yang berarti kebekerjaan lulusan SMK adalah $65 \%$. Jumlah lulusan SMK yang bekerja mandiri (wirausaha) sebesar 5\%. Lulusan SMK yang bekerja sambil kuliah sebesar 5\%, sedangkan lulusan yang melanjutkan kuliah sebesar $8 \%$. Lebih lengkap dilihat di tabel 4 .

Tabel 4. Tingkat Kebekerjaan Lulusan SMK

\begin{tabular}{|c|l|c|c|c|c|c|c|c|c|}
\hline \multirow{2}{*}{ No } & \multicolumn{2}{|c|}{ Indikator } & \multicolumn{2}{|c|}{$2010 / 2011$} & \multicolumn{2}{l|}{$2011 / 2012$} & \multicolumn{2}{l|}{$2012 / 2013$} & \multicolumn{2}{l|}{$2013 / 2014$} \\
\cline { 3 - 10 } & Jumlah & $\%$ & Jumlah & $\%$ & Jumlah & $\%$ & Jumlah & $\%$ \\
\hline 1 & Jumlah Lulusan & 1010339 & & 1086387 & & 1169218 & & 1241398 & \\
\hline 2 & $\begin{array}{l}\text { Jumlah Lulusan } \\
\text { yang Bekerja }\end{array}$ & 556797 & 55 & 632385 & 58 & 730059 & 62 & 804674 & 65 \\
\hline 3 & $\begin{array}{l}\text { Jumlah Lulusan } \\
\text { yang bekerja } \\
\begin{array}{l}\text { Mandiri } \\
\text { (Wirausaha) }\end{array}\end{array}$ & 50153 & 5 & 55141 & 5 & 61337 & 5 & 68028 & 5 \\
\hline 4 & $\begin{array}{l}\text { Jumlah Lulusan } \\
\text { yang BEKERJA } \\
\text { sambil Kuliah }\end{array}$ & 51527 & 5 & 56492 & 5 & 61968 & 5 & 68276 & 5 \\
\hline 5 & $\begin{array}{l}\text { Jumlah lulusan } \\
\text { yang Melanjutkan } \\
\text { Kuliah }\end{array}$ & 71835 & 7 & 79306 & 7 & 88860 & 8 & 98070 & 8 \\
\hline
\end{tabular}

Berdasarkan tabel 4, lulusan SMK yang menganggur masih 17\%. Dengan demikian, jumlah tersebut harus diturunkan melalui penyelenggaraan pendidikan kejuruan yang efektif.

Pendidikan kejuruan yang berlangsung sampai sekarang ini banyak dipengaruhi oleh teori yang diajukan oleh Charles A. Prosser yang dikenal dengan 16 Teorema Prosser (Prosser's Sixteen Theorems). Teori-teori dalam pendidikan kejuruan tersebut ditulis oleh Prosser dan Quigley (1950: 215-232). Teori-teori di atas didasarkan pada pernyataan keduanya bahwa pendidikan kejuruan harus membangun kebiasaan (habits), yaitu kebiasaan berpikir yang benar dan perbuatan yang benar. Dalam teorema tersebut di antaranya disebutkan bahwa pendidikan kejuruan yang baik menyediakan kebiasaankebiasaan yang akan berlaku di dunia kerja. 
Camp dan Hillison (1984: 20) menyimpulkan bahwa teorema Prosser telah membentuk dasar pengembangan pendidikan kejuruan sampai sekarang.

Dengan konsep pendidikan kejuruan dalam hal ini SMK saat ini, dalam 5 tahun ke depan
(2015-2019) pemerintah telah menentukan target untuk SMK melalui meningkatan jumlah SMK, jumlah siswa, jumlah lulusan, serta persentase kebekerjaan yang dapat dilihat pada tabel 5.

Tabel 5. Target SMK 2015-2019

\begin{tabular}{clcccccc}
\hline No & \multicolumn{1}{c}{ Indikator } & 2014 & 2015 & 2016 & 2017 & 2018 & 2019 \\
\hline 1 & Jumlah Siswa & 4512063 & 4725078 & 4949681 & 5136752 & 5269447 & 5376671 \\
2 & APK (\%) & 34 & 36 & 37 & 39 & 39 & 40 \\
3 & SMK & 11748 & 11850 & 11952 & 12058 & 12170 & 12287 \\
4 & SMK Rujukan & 300 & 570 & 840 & 1110 & 1380 & 1650 \\
5 & Lulusan yang Bekerja (\%) & 65 & 67 & 69 & 71 & 73 & 75 \\
6 & $\begin{array}{l}\text { Lulusan yang bekerja Mandiri } \\
\text { (Wirausaha) (\%) }\end{array}$ & 5 & 5.5 & 6.0 & 6.5 & 7 & 7.5 \\
7 & $\begin{array}{l}\text { Lulusan yang Bekerja sambil } \\
\text { Kuliah (\%) } \\
\text { Lulusan yang Melanjutkan }\end{array}$ & 5 & 5.3 & 5.6 & 6.2 & 6.5 & 7 \\
Kuliah (\%) & 8 & 8 & 8 & 8 & 8 & 8 \\
\hline
\end{tabular}

Berdasarkan tabel 5, peningkatan jumlah SMK, siswa, sampai jumlah kebekerjaan baru sebatas peningkatan kuantitas, namun belum nampak peningkatan kualitas dalam kompetensi lulusan. Dari data lulusan SMK yang menganggur di atas dapat diduga bahwa kualitas lulusan SMK selama ini relatif masih rendah.

Direktorat Pembinaan SMK Kementerian Pendidikan dan Kebudayaan telah merencanakan dan melaksanakan berbagai program unggulan SMK yaitu: (1) Peningkatan akses dan relevansi, (2) Sertifikasi LSP 1: TUK, sertifikasi kompetensi, (3) Ujian Nasional on-line untuk teori kejuruan, (4) Teaching Factory/Business Center/Teaching Industry, (5) Pemenuhan Kurikulum 2013, (6) SMK Pondok Pesantren/Berbasis Komunitas/SMK PublicPrivate -Partneship, dan (7) Peningkatan Mutu SMK: SMK Rujukan, SMK di Industri, dan lainnya.

Direktur Pembinaan SMK tahun 2014, Mustaghfirin Amin (2014) mengatakan, bahwa Kemendikbud berkerjasama dengan Badan Nasional Sertifikasi Profesi (BNSP), dan asosiasi industri perlu memberikan sertifikat keahlian bagi anak-anak SMK. Siswa SMK untuk mendapatkan sertifikat keahlian cukup diuji di SMK
Rujukan, mereka tidak perlu membayar sertifikat dengan biaya mahal. http://www.acehxpress.com/2014/08/pemerint ah-yakin-lulusan-smk-siap.html (diunduh 24 des 2015 jam 12.53 wib)

Berdasarkan uraian di atas maka untuk menyiapkan lulusan SMK agar siap bersaing dalam MEA salah satunya dengan cara memberikan sertifikasi keahlian. Dengan memiliki sertifikat keahlian yang dikeluarkan oleh industri atau lembaga sertifikasi, kompetensi lulusan SMK akan diakui oleh negara-negara anggota ASEAN. Kaitannya dengan kompetensi, McAshan (1979:38) menyatakan bahwa: "competence represent the cognitive, affective, and psychomotor learning outcomes established for or by the learner." Selanjutnya McAshan (1979: 45) menyatakan bahwa kompetensi adalah: "....the knowledge, skills, and abilities or capabilities that a person achieves, which become part of his or her being to the extent he or she can satisfactory perform particular cognitive, affective, and psychomotor behaviors......". Dengan demikian, kompetensi adalah hasil belajar kognitif, afektif, dan psikomotor yang dicapai oleh seseorang. Kompetensi juga dimaknai sebagai pengetahuan, keterampilan, dan kemampuan yang dicapai seseorang yang menjadi bagian kehidupannya yang dapat 
dikembangkan dan dapat ditunjukkan dengan perilaku kognitif, afektif dan psikomotor. Dengan adanya sertifikat, maka kemampuan tersebut dapat diakui oleh industri di ASEAN.
Sertifikat keahlian tersebut dapat diperoleh melalui uji kompetensi produktif. Alur pemikiran sertifikasi tersebut dapat dilihat di dalam gambar 1 .

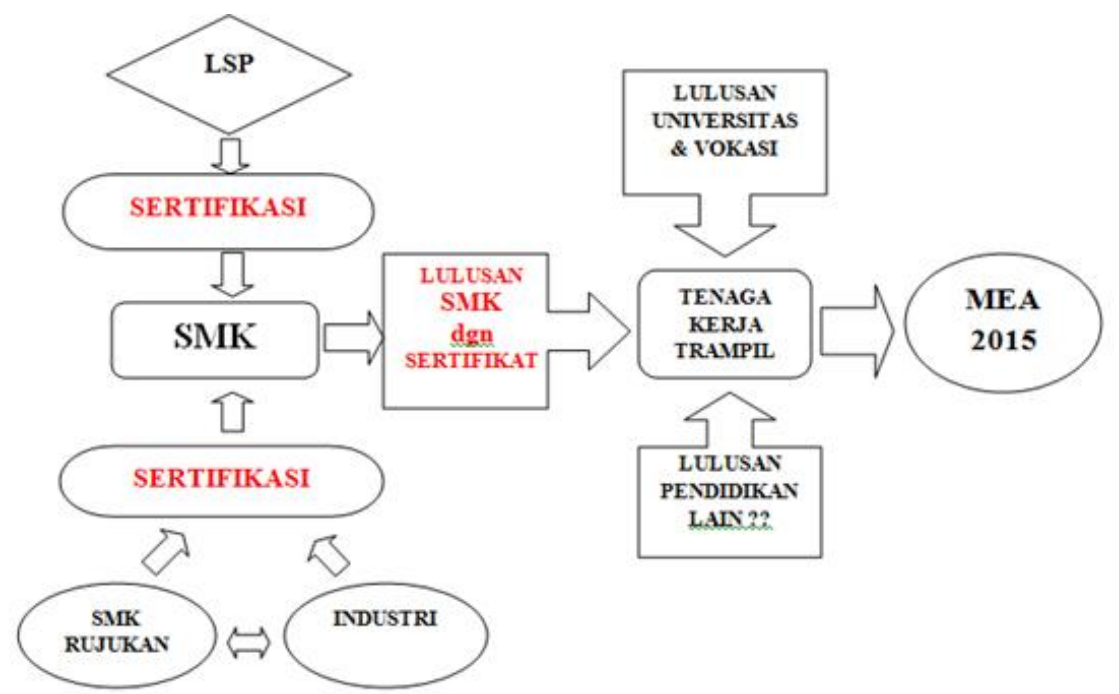

Gambar 1. Alur pemikiran sertifikasi keahlian lulusan SMK

Sertifikasi keahlian diberikan oleh dunia usaha/ industri (DU/DI) atau lembaga sertifikasi di luar SMK. Sertifikat akan diberikan kepada lulusan SMK yang lulus uji kompetensi yang dilakukan oleh DU/DI atau lembaga sertifikasi. Uji kompetensi produktif juga dapat dilakukan melalui kerjasama antara SMK Rujukan dan DU/DI. Keterkaitan antara proses pembelajaran dan sertifikasi kompetensi di SMK berdasarkan aturan Direktorat Pembinaan SMK yang dipaparkan pada gambar 2 .

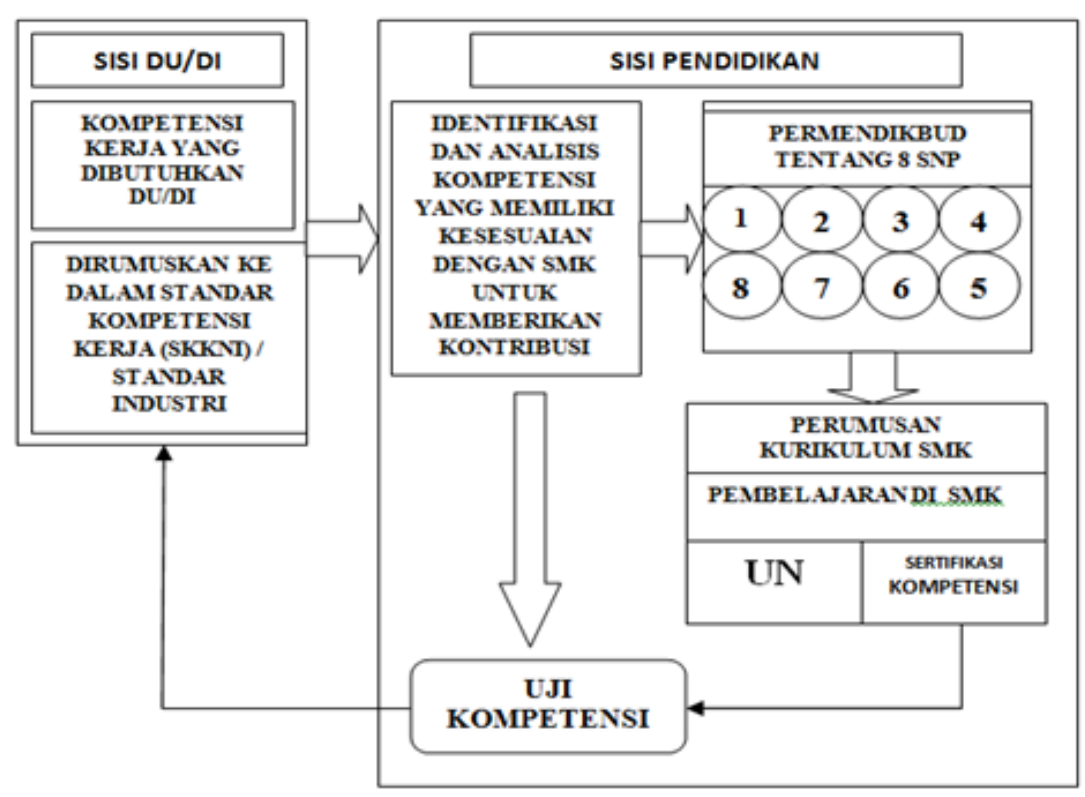

Gambar 2. Kerangka alur pikir proses pembelajaran dan sertifikasi kompetensi di SMK saat ini 
Berdasarkan gambar di atas, uji kompetensi dan sertifikasi dipaparkan karena adanya keterkaitan sisi DU/DI dan sisi pendidikan. Sisi DU/DI memerlukan kompetensi kerja yang dirumuskan ke dalam (SKKNI). Sisi pendidikan melakukan identifikasi dan analisis kompetensi kerja yang dilaksanakan di SMK melalui 8 Standar Nasional Pendidikan. Kompetensi yang dirumuskan dalam isi kurikulum SMK dilaksanakan dengan pembelajaran. Kegiatan pembelajaran diakhiri dengan ujian nasional dan juga uji kompetensi yang dilakukan oleh guru yang memiliki sertifikat asesor dengan melibatkan DU/DI. Idealnya, SMK melakukan uji kompetensi dan sertifikasi keahlian sekaligus untuk menentukan kelulusan peserta didik. Namun faktanya belum semua SMK mempunyai hubungan kemitraan dengan DU/DI. Beberapa DU/DI yang memiliki hubungan kemitraan yang baik dengan SMK melakukan uji kompetensi sendiri setelah uji kompetensi di sekolah. Peserta didik yang lulus uji komepetensi yang dilakukan oleh DU/DI sendiri ini akan diberikan sertifikat keahlian pada tingkat awal (level 1).

Dengan adanya uji kompetensi tersebut, bagaimanakah profil kompetensi produktif siswa SMK paket keahlian TKR yang mengikuti uji kompetensi? Apakah kompetensi produktif siswa SMK sebagai calon tenaga kerja terampil sudah sesuai dengan kompetensi yang dbutuhkan oleh DU/DI?

\section{METODE}

Penelitian mengenai profil kompetensi produktif siswa SMK paket keahlian Teknik Kendaraan Ringan dalam rangka sertifikasi keahlian ini dilakukan dengan pendekatan survei. Pendekatan survei dipandang sesuai karena menjaring data mengenai materi dan hasil uji kompetensi produktif siswa klas 3 SMK paket keahlian Teknik Kendaraan Ringan, dan kendala dalam uji kompetensi produktif dengan jumlah yang cukup banyak.

Populasi penelitian ini adalah semua siswa klas 3 SMK Negeri di daerah Istimewa
Yogyakarta yang memiliki paket keahlian TKR. Di Daerah Istimewa Yogyakarta terdapat 15 SMK Negeri yang memiliki paket keahlian TKR yang tersebar di 5 kabupaten/kota. Sampel diambil dengan teknik sampling purposif yaitu mengambil sampel pada satu SMK Negeri di tiap kabupaten/kota dengan pertimbangan bahwa tiap SMK Negeri mempunyai sistem uji kompetensi yang lebih baik daripada SMK swasta (5 SMK Negeri). Sekolah sampel adalah: SMK Negeri 2 Pengasih, SMK Negeri 1 Sedayu, SMK Negeri 1 Seyegan, SMK Negeri 2 Yogyakarta, dan SMK Negeri 2 Wonosari. Jumlah siswa klas 3 SMK Negeri yang diambil di tiap SMK adalah satu kelas (sekitar 33-35 siswa), sehingga jumlah sampelnya sekitar $=33 \times 5=165-175$ siswa.

Sumber data hasil uji kompetensi di atas adalah tim penguji UPK yang melakukan pengujian terhadap siswa klas 3 SMK paket keahlian Teknik Kendaraan Ringan tersebut. Pengambilan data dilakukan dengan metode dokumentasi dan wawancara, sehingga instrumen yang digunakan adalah pedoman wawancara, dan lembar dokumen. Selanjutnya, data penelitian dianalisis dengan analisis deskriptif kuantitatif yang berbentuk persentase, dan analisis deskriptif kualitatif berbentuk uraian verbal.

\section{HASIL DAN PEMBAHASAN}

Uji Praktik Kejuruan Teknik Kendaraan Ringan tahun 2015/ 2016 menggunakan dua model soal. Soal model pertama, seperti soal tahun 2014/ 2015, diunggah jauh-jauh hari sebelum pelaksanaan, yang terdiri 1 paket dengan 4 mata uji, yaitu: 1) Overhaul $O H C$ Engine; 2) Tune-up dan Perbaikan Engine Management System; 3) Overhaul Manual Transmission $(M / T)$; 4) Menginstalasi dan Memperbaiki Body Electrical System.

Soal model kedua diupload 2 hari sebelum pelaksanaan, terdiri dari 3 paket yang masing-masing paket terdiri 8 mata uji, namun setelah dicermati ternyata untuk Paket 2 dan Paket 3 ternyata sama. Paket 1 berisi : 1) Tune Up Gasoline Engine Konvensional; 2) 
Perawatan/ Perbaikan Engine dan komponenkomponennya; 3) Perawatan/ Perbaikan Unit Kopling; 4) Perawatan/ Perbaikan Transmisi manual; 5) Perawatan/ Perbaikan Unit final drive/gardan; 6) Perawatan/ Perbaikan Sistem Rem; 7) Pemeriksaan dan Penyetelan roda depan (FWA); 8) Perawatan/ Perbaikan Sistem Kelistrikan Bodi Standar.

Paket 2 berisi: 1) Tune Up Diesel Engine Konvensional; 2) Perawatan/ Perbaikan Engine dan komponenkomponennya; 3) Perawatan/ Perbaikan Unit Kopling; 4) Perawatan/ Perbaikan Transmisi manual; 5) Perawatan/ Perbaikan Unit final drive/ gardan; 6) Perawatan/ Perbaikan Sistem Rem; 7) Pemeriksaan dan Penyetelan roda depan (FWA); 8) Perawatan/ Perbaikan Sistem Kelistrikan Bodi Standar.

Pada soal model kedua yang membedakan dari ketiga paket tersebut adalah pada mata uji pertama saja, sedangkan untuk mata uji kedua sampai dengan kedelapan sama. Mata uji pertama dari paket I adalah tune-up mesin bensin konvensional, sedangkan untuk paket kedua adalah tune-up mesin bensin EFI dan untuk paket ketiga adalah tuneup mesin diesel konvensional. Setelah dicermati ternyata ada kesalahan bunyi soal penugasan pada paket ke-2 yang seharusnya tune-up mesin bensin EFI, namun tertulis tuneup mesin diesel konvensional. Hal tersebut diduga yang menjadi penyebab kenapa terjadi dua kali upload paket soal Uji Kompetensi dari direktorat PSMK.

Ada beberapa metode yang dilakukan oleh SMK dalam memilih paket yang ditawarkan. SMK N 2 Yogyakarta, SMK N 2 Wonosari dan SMK N 2 Pengasih (60\%) memilih paket pertama yang ada Tune-Up mobil bensin EFI karena dinilai lebih mengikuti perkembangan. SMK N Seyegan dan SMK N Sedayu (40\%) memilih paket versi upload kedua pada Paket 1 yang berisi Tune-Up mobil bensin konvensional, karena persiapan siswa yang diarahkan pada mobil bensin konvensional dan kondisi daya dukung lainnya. Kondisi ini diluar dugaan awal, dikarenakan setiap pelaksanaan UPK pada tahun-tahun sebelumnya paket uji selalu sama jumlah mata ujinya..

Dilihat dari paket soal yang dipilih maka profil kompetensi siswa pada UPK ini dapat teramati bahwa : Di SMK N 2 Yogyakarta (106 siswa), SMK N 2 Wonosari (94 siswa) dan SMK N 2 Pengasih (95 siswa) terdapat 4 unit dan atau klaster kompetensi, yaitu Overhaul OHC Engine, Tune-up dan Perbaikan Engine Management System, Overhaul Manual Transmission (M/T), dan Menginstalasi dan Memperbaiki Body Electrical System. Sedangkan di SMK N 1 Seyegan (106 siswa) dan SMK N Sedayu (92 siswa) terdapat 8 unit dan atau kluster kompetensi, yaitu Tune Up Gasoline Engine Konvensional, Perawatan/ Perbaikan Engine dan komponen-komponennya, Perawatan/ Perbaikan Unit Kopling, Perawatan/ Perbaikan Transmisi manual, Perawatan/ Perbaikan Unit final drive/ gardan, Perawatan/ Perbaikan Sistem Rem, Pemeriksaan dan Penyetelan roda depan (FWA), Perawatan/ perbaikan Sistem Kelistrikan Bodi Standar.

Pelaksanaan UPK dilakukan di sekolah dengan penguji internal dan eksternal. Penguji Internal adalah guru produktif baik yang mempunyai sertifikat asesor dari BNSP/ sertifikat kompetensi dari LSP ataupun yang tidak memiliki sertifikat. Penguji eksternal dari unsur industri bengkel otomotif, antara lain Nasmoco Janti (Toyota), Daihatsu Jokteng, Dicky Auto Servis dan beberapa bengkel lokal lainnya. Selain itu, SMK N 2 Wonosari mengambil penguji eksternal dari instruktur Balai Latihan Kerja. Setiap SMK hanya melibatkan 2 atau 3 penguji eksternal.

Model penilaian oleh asesor bervariasi, ada yang satu peserta dinilai oleh dua penguji yaitu internal dan ekternal secara terpisah, serta dengan satu lembar penilaian yang disepakati oleh penguji internal dan eksternal. Teknik pengamatan penilaian juga ada yang satu penguji menilai satu siswa pada satu mata uji dan ada juga yang menilai banyak siswa pada banyak mata uji. Secara faktual memang masih ada asesor eksternal yang belum melakukan penilaian sepenuhnya. 
Penguji eksternal pada dasarnya mengapresiasi bagus adanya UPK. Namun pelaksanaannya belum berjalan dengan baik. Mayoritas asesor berpendapat, jika UPK dilaksanakan secara ketat, diduga hanya sekitar 50\% siswa yang berhasil di atas KKM dan hanya berkisar di bawah $25 \%$ yang kompeten sepenuhnya.

Penskoran UPK antar sekolah menggunakan 2 model penskoran, yaitu model 0 dan 1 atau go dan no go untuk model yang pertama dan model skala 1, 2, 3 dan 4 yang disetarakan dengan model "tidak kompeten", "kompeten 7-8", “kompeten 8-9" dan "kompeten 9-10". Pada penskoran model 0 dan 1, terdapat SMK yang mengikuti sepenuhnya pedoman penskoran, yaitu skor masing-masing komponen penilaian ditetapkan berdasarkan perolehan skor terendah dari subkomponen penilaian sebagaimana terlihat pada Tabel 6, namun ada yang menggunakan jumlah perolehan skor sebagaimana terlihat pada tabel 7 .

Tabel 6. Penilaian oleh SMK N 2 Pengasih

Perhitungan nilai praktik (NP) :

\begin{tabular}{|c|c|c|c|c|c|c|}
\cline { 2 - 6 } & \multicolumn{5}{|c|}{ Prosentase Bobot Komponen Penilaian } & Nilai Praktik \\
\cline { 2 - 6 } & Persiapan & Proses & Sikap Kerja & Hasil & Waktu & $\sum$ NK \\
\cline { 2 - 6 } & 1 & 2 & 3 & 4 & 5 & 6 \\
\hline Bobot (\%) & $10 \%$ & $50 \%$ & $10 \%$ & $25 \%$ & $5 \%$ & \multirow{2}{*}{$\mathbf{9 5 . 0 0}$} \\
\hline Skor Komponen & 1.00 & 1.00 & 1.00 & 1.00 & - & 0 \\
\hline \hline
\end{tabular}

Tabel 7. Penilaian oleh SMK N 2 Yogyakarta, Wonosari

\begin{tabular}{|c|c|c|c|c|c|c|}
\cline { 2 - 7 } \multicolumn{1}{c|}{} & Persiapan & Proses & Sikap Kerja & Hasil & Waktu & Nilai Praktik \\
\cline { 2 - 7 } & $\mathbf{2}$ butir & $\mathbf{2 9}$ butir & $\mathbf{5}$ butir & 5 butir & 3 butir & $\sum$ NK \\
\hline Bobot (\%) & $10 \%$ & $50 \%$ & $10 \%$ & $25 \%$ & $5 \%$ & $100 \%$ \\
\hline Skor Komponen & 2.00 & 26.00 & 4.00 & 4.00 & 2.00 & \\
\hline NK & 10 & 44.83 & 8.00 & 20 & 3.33 & $\mathbf{8 6 . 1 6}$ \\
\hline
\end{tabular}

Tabel 8. Tingkat kelulusan UPK tahun 2015/2016

\begin{tabular}{|c|l|c|c|c|c|}
\hline No & \multicolumn{1}{|c|}{ Nama SMK } & $\Sigma$ Peserta & $\Sigma$ Lulus & $\Sigma$ Tidak Lulus & \% Kelulusan \\
\hline 1. & SMK N 2 Yogyakarta & 106 & 102 & 4 & $96.26 \%$ \\
\hline 2. & SMK N Seyegan & 106 & 105 & 1 & $99.06 \%$ \\
\hline 3. & SMK N Sedayu & 93 & 91 & 2 & $97.85 \%$ \\
\hline 4. & SMK N 2 Wonosari & 94 & 92 & 2 & $97.87 \%$ \\
\hline 5. & SMK N 2 Pengasih & 95 & 95 & 0 & $100 \%$ \\
\hline \multicolumn{4}{|c|}{ Rata-rata } \\
\hline
\end{tabular}

Tabel 8 menunjukkan tingkat kelulusan UPK di SMK dengan tingkat kelulusannya $98.21 \%$. Siswa yang tidak lulus sebagian besar dikarenakan tidak mengikuti UPK. Namun terdapat beberapa catatan pada pelaksanaan
UPK-nya antara lain: 1) Siswa yang belum kompeten diharuskan remedial sampai kompeten dengan pengulangan uji pada bagian yang tidak kompeten sampai benar-benar kompeten; 2) Siswa dinyatakan kompeten 
walaupun sampai batas waktu uji belum selesai dengan catatan siswa tersebut diberi perpanjangan waktu tidak terbatas sampai kompeten; 3) Teknis penskoran berbeda sehingga menghasilkan rentang nilai yang berbeda.

Data pencapaian rata-rata nilai akhir UPK pada lima SMK yang dijadikan sampel penelitian dapat dilihat pada gambar 3 .

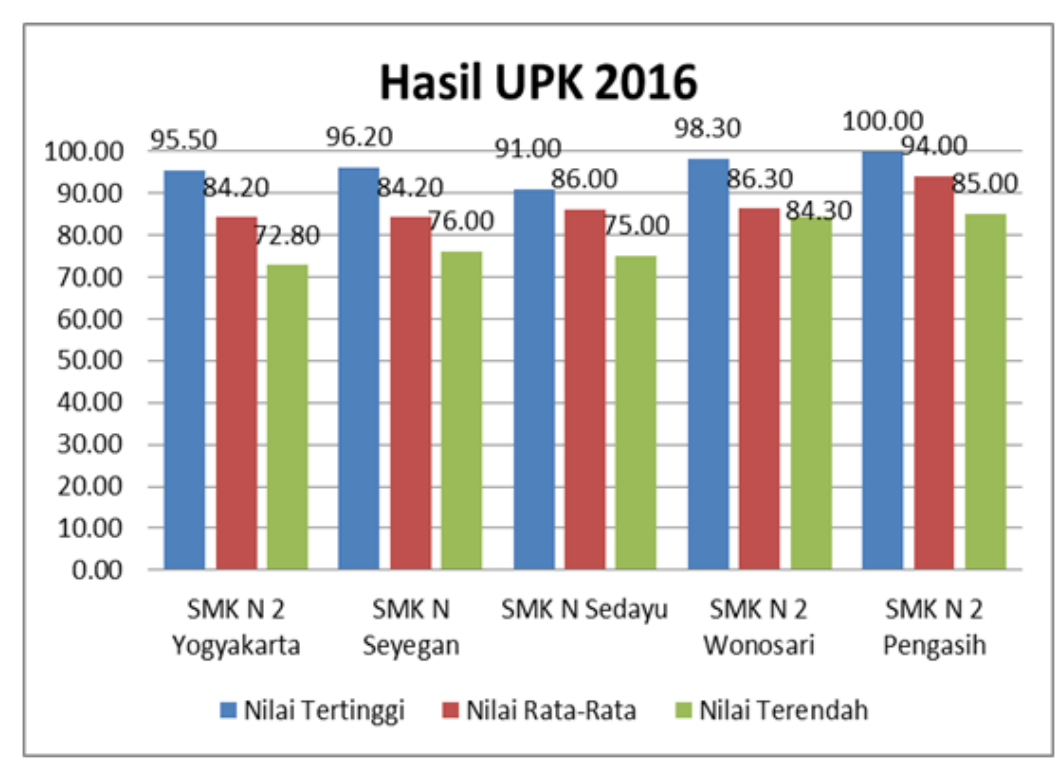

Gambar 3. Diagram hasil UPK 2016 pada 5 SMK Sampel

Tabel 9. Capaian nilai rata-rata pada setiap mata uji (model 4 mata uji)

\begin{tabular}{cccccc}
\hline \multirow{2}{*}{ No } & Nama SMK & \multicolumn{4}{c}{ RATA-RATA } \\
\cline { 3 - 5 } & SMK N 2 Yogyakarta & TUNE-UP & TRANSMISI & OH MESIN & $\begin{array}{c}\text { LISTRIK } \\
\text { BODI }\end{array}$ \\
\hline 1 & SMK N 2 Wonosari & 83.43 & 85.68 & 80.88 & 86.95 \\
\hline 2 & SMK N 2 Pengasih & 92.02 & 89.47 & 91.22 & 95.63 \\
\hline 3 & & 93.89 & 93.89 & 93.89 & 93.89 \\
\hline
\end{tabular}

Tabel 10. Capaian nilai rata-rata pada setiap mata uji (model 8 mata uji)

\begin{tabular}{|c|c|c|c|c|c|c|c|c|c|}
\hline \multirow{2}{*}{ No } & \multirow{2}{*}{ Nama SMK } & \multicolumn{8}{|c|}{ RATA-RATA } \\
\hline & & Tune Up & Overhoul & Kopling & Transmisi & Diffrential & Rem & FWA & Kelistrikan \\
\hline 1 & SMK N Seyegan & \multicolumn{8}{|c|}{ Data tidak tersedia } \\
\hline 2 & SMK N Sedayu & 83.98 & 84.56 & 81.98 & 85.56 & 87.65 & 85.23 & 90.30 & 86.02 \\
\hline
\end{tabular}

Hasil UPK (tabel 9 dan 10) yang dicapai oleh SMK mayoritas bagus. Tingkat kelulusan peserta adalah 98.21\%. Hal tersebut menunjukkan prestasi yang dicapai sangat bagus, walaupun jika dicermati dari prosesnya masih perlu dibenahi. Keprofesionalan pelaksanaan uji masih belum terjaga dengan baik. Hal itu disampaikan oleh panitia UPK pada mayoritas SMK, bahwa pelaksanaan uji tidak ketat dalam durasi waktu. Banyak peserta yang diberi tambahan waktu, sebagaimana terlihat pada data SMK N 2 Pengasih dan SMK N 2 Yogyakarta yang $75 \%$ dan $48 \%$ melebihi batas waktu yang disediakan, bahkan pada overhaul di SMK N 2 Yogyakarta, $80 \%$ siswa gagal dari segi waktu. Sebagian sekolah yang tidak memberikan perpanjangan waktu, menggunakan remedial. 
Remidial juga tidak ideal, namun hanya pada poin ketidakberhasilannya saja serta waktu yang tidak ketat. Setelah melaksanakan remedial, dan lulus uji, maka siswa dapat dinyatakan berhasil.

Keberhasilan menempuh UPK dibuktikan dengan sertifikat kompetensi. Batas nilai lulus adalah 76. Siswa yang lulus UPK mendapatkan surat keterangan atau sertifikat kompetensi yang dikeluarkan oleh sekolah dan diketahui oleh institusi mitra. Institusi mitra ada beberapa jenis, seperti bengkel mobil, balai latihan kerja, atau majelis pendidikan kejuruan daerah.

Setelah pelaksanaan UPK selesai, jika ada tawaran program dari BNSP melalui LSP, SMK mengirimkan siswa untuk mengikuti Uji Kompetensi. Uji Kompetensi tersebut tidak ada keterkaitannya dengan UPK yang diselenggarakan sekolah. Pada umumnya sekolah mengirim siswa/alumni untuk mengikuti Uji Kompetensi dengan mempertimbangkan hasil UPK. Pada praktiknya, pemanggilan alumni terkadang terhambat oleh putusnya komunikasi sekolah alumni, sehingga peserta yang dikirim Uji Kompetensi adalah siswa atau alumni yang bisa dihubungi oleh pihak sekolah.

Kaitannya dengan kerjasama dalam pelaksanaan uji kompetensi, belum ada SMK yang secara ekplisit terlibat kerjasama dengan BNSP atau LSP dalam pelaksanaan UPK, sehingga pelaksanaan UPK tidak terintegrasi dengan sistem sertifikasi profesi atau sertifikasi kompetensi yang independen dan sesuai legalitasnya. Hal tersebut dikarenakan kurangnya komunikasi antara SMK dan LSP/ BNSP dan juga karena kekhawatiran SMK jika dimasukkan skema sertifikasi melalui lembaga yang professional dan independen, banyak siswanya tidak lulus uji. Selain itu model pengujiannya juga berbeda pada aspek penilaiaannya, sehingga perlu komunikasi lebih intensif untuk teknis konversi penilaiannya.

\section{SIMPULAN}

Berdasarkan hasil penelitian, dapat disimpulkan bahwa: Pertama, materi Uji Praktik Kejuruan SMK TKR di DIY tahun ajaran 2015/2016 terdiri dari 2 model, model pertama dengan 4 mata uji, yaitu Overhaul OHC Engine, Tune-up dan Perbaikan Engine Management System, Overhaul Manual Transmission $(M / T)$, dan Menginstalasi dan Memperbaiki Body Electrical System dan model kedua UPK dengan 8 mata uji yaitu Tune Up Gasoline Engine Konvensional, Perawatan/ Perbaikan Engine dan komponenkomponennya, Perawatan/ Perbaikan Unit Kopling, Perawatan/ Perbaikan Transmisi manual, Perawatan/ Perbaikan Unit final drive/ gardan, Perawatan/ Perbaikan Sistem Rem, Pemeriksaan dan Penyetelan roda depan (FWA), Perawatan/ perbaikan Sistem Kelistrikan Bodi Standar.

Kedua, penguji Uji Praktik Kejuruan SMK TKR di DIY tahun ajaran 2015/2016 adalah guru bersertifikat asesor dari BNSP, guru bersertifikat kompetensi tertentu dari LSP, guru produktif tanpa sertifikat BNSP atau LSP, unsur dunia usaha/ dunia industri jasa servis kendaraan dan instruktur BLK bersertifikat asesor.

Ketiga, hasil Uji Praktik Kejuruan SMK TKR di DIY tahun ajaran 2015/2016 jika dilihat dari nilai akhir dan kelulusan adalah sangat bagus, walaupun jika dilihat secara proses, nilai tersebut belum mencerminkan kompetensi peserta uji sepenuhnya.

Keempat, sertifikasi bagi peserta Uji Praktik Kejuruan SMK TKR di DIY tahun ajaran 2015/2016 dikeluarkan oleh SMK itu sendiri dengan bekerjasama dengan institusi mitra, yaitu bengkel jasa servis kendaraan, MPKD, dan BLK. Belum ada yang tersertifikasi oleh lembaga sertifikasi yang sesuai dengan peraturan perundangan yang berlaku. 


\section{DAFTAR PUSTAKA}

Anonim. (t.th.). Menuju ASEAN Economic Community. Jakarta: Departemen Perdagangan RI.

Anonim. (t.th.). Competence. http://www.businessdictionary.com/defi nition/ competence.html diakses tanggal 28 Januari 2015.

Badan Pusat Statistik. (2014). Keadaan Ketenagakerjaan Februari 2014. Berita Resmi Statistik. No. 38/05/Th. XVII, 5 Mei 2014, h. 1-5.

Camp, William G. and Hillison, John H. (1984). Prosser's sixteen theorems: time for reconsideration. Journal of Vocational and Technical Education. Vol. 1 (1) Fall, 1984, pp.13-20.

Clarke, Linda and Winch, Christopher (editor). (2007). Vocational Education: International approach, developments and systems. London: Routledge.
Evans, Rupert N. (1971). Foundations of Vocational Education. Columbus: Charles E. Merrill Publishing Company.

McAshan, H.H. (1979). Competency-based Education and Behavioral Objectives. Englewoods Cliffs: Educational Technology Publications, Inc.

Mustaghfirin Amien. (2014). Pemerintah Yakin, Lulusan SMK Siap hadapi MEA 2015. Aceh Xpress. Banda Aceh: 24 Agustus 2014. http://www.acehxpress.com/2014/08/pe merintah-yakin-lulusan-smk-siap.html diakses tanggal 24 Desember 2014.

Prosser, Charles A. and Quigley, Thos H. (1950). Vocational Education in a Democrazy. (Revised Edition). Chicago: American Technical Society.

Thompson, John F. (1973). Foundations of Vocational Education: Social and Philosophical Concepts. Englewood Cliffs: Prentice-Hall, Inc. 